\title{
Beyond Signature Literacy: New Research Directions
}

\section{Bruce Curtis}

An October 1835 petition to the colonial government of Lower Canada seeking an act of incorporation for the Collège de Chambly contained the names of over 800 men. Yet only thirteen of them, led by Dr. J.-B. Meilleur (later Assistant Superintendent of Education), actually signed the petition. Indeed, they signed not once but twice, once at the beginning and a second time at the end of the list of names, adding the comment 'Nous Soussignés certifions que les Signature cidessus accompagnées d'une croix Chacune ont été par nous prises aux fins de la requête qui les précede. ${ }^{1}$ The Lower Canadian government archive abounds with documents like the college petition, and on many of them some people's signatures are inscribed as proof that the marks made by others were in fact those other people's marks. Such documents range in size from the celebrated 1827 petition to the Crown in support of the grievances of the Assembly, said to contain 87,000 names but only 9,000 signatures, to the myriad of minor documents where single individuals, or groups large or small, had occasion to sign — or not to sign — their names. ${ }^{2}$

Such documents fueled contemporary debate over cultural development and political rule. Opponents of the demands made in the more overtly political petitions were quick to argue that those who did not sign could not sign; that those who could not sign could not read; and that those who could not read could not understand their political interests. Many historians of literacy have shared at least some of these propositions, especially taking the fact of signing as an indication of the signer's ability to read. It has been argued in support of such a position that writing comes after reading in the process of instruction, thus a signer is a writer, and a writer is a reader. The percentage of people who sign documents, especially civil registers, where all who can sign are required in principle to do so, is presented as the best available measure of the degree of literacy in a population. iii Variations in signing rates among different categories of population come then to be educational inequalities to be explained.

The contributors to this special issue on literacy concur in regarding such an approach as dubious methodologically and as a relatively unimaginative treatment of the 


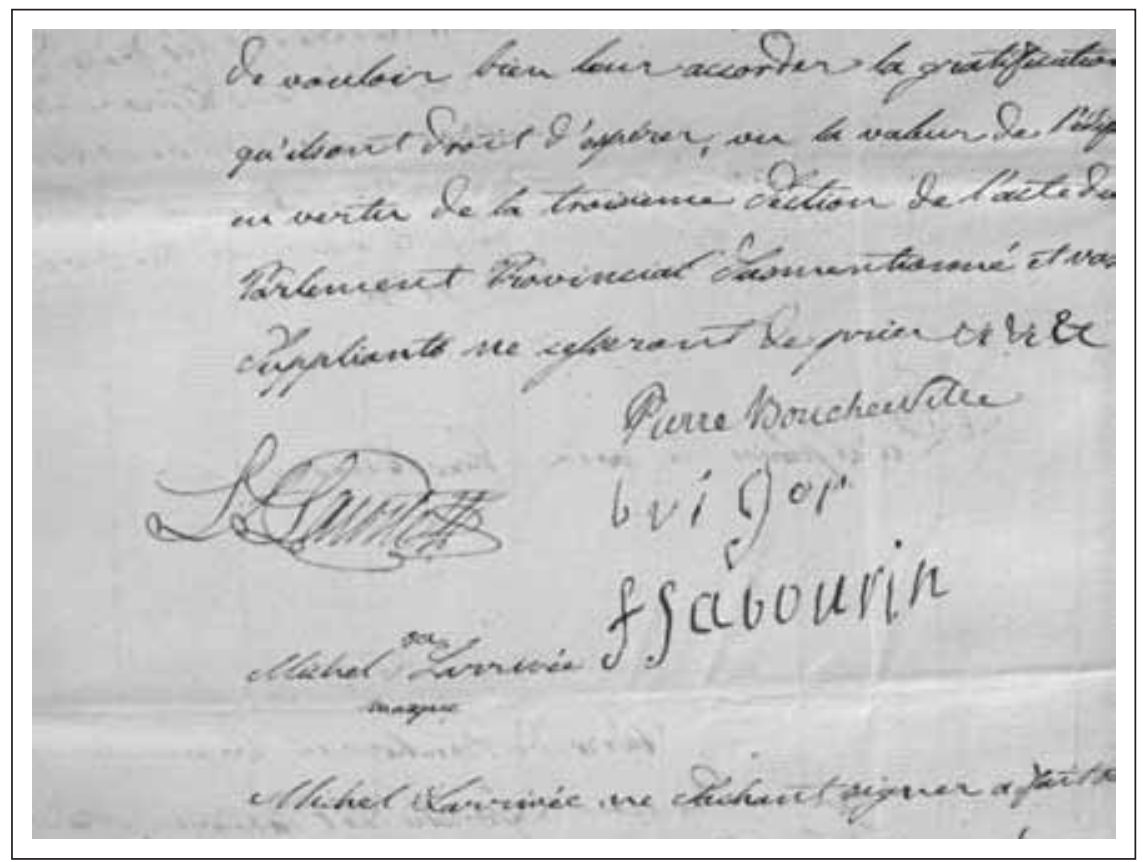

Source: Library and Archives Canada, RG4 A1 vol. 312. Signatures of school Trustees in Boucherville parish, 1830. Included are that of the seigneur Boucherville, Louis Lacoste, a local notable, the infamous wealthy peasant, Bonaventure Viger, later transported for his activities in 1837, and two others, including Michel Larrivée who made his ' $x$.'

complex of practices and events that might be described as literacy. The approach tends to narrow a broad field of social practices — what Dorothy Smith called 'textually mediated social relations ${ }^{34}$ - to a seemingly simple scriptoral act. Yet the signature is not a fixed entity or a unitary object, as my opening example illustrates. The significance of a signature on a document is constituted in and governed by a textual economy ${ }^{5}$ - the distribution of signatures in text, for instance, and their relation to other aspects of textual organization - and by political economies - the social position and interests of signers. In effect, the meaning of the identical signs produced by the thirteen Chambly petitioners differed with placement in their petition, in keeping with the likely reading strategies of the government officers who encountered them. Seeing their signatures at the beginning, government officers may have viewed the thirteen first as participants in a collective enterprise. Seeing their signatures at the end, the same officers were invited to see them as guarantors, men who by signing could make the marks of others into signatures. That others marked but did not write their names may have led to various kinds of speculation as to the worth of the petition. And perhaps having seen the thirteen as guarantors, government officials may have returned to the beginning of the petition - as I did - to reflect on the order in which they signed and on their social standing as ways of estimating the import of the document. Signatures are social performances and are 
thus to be understood in the complex of social relationships and practices in which they are embedded.

The deeper and more complex history of the signature and of related practices of signification is explored by François Melançon, following in part the work of Béatrice Fraenkel, ${ }^{6}$ in his essay on the polysemic nature of signing in New France. It is only comparatively recently - with the formation of modern states - that the signature alone, without such other supports as seals, designs and verbal affirmations, has come to be accepted as an unambiguous marker of individual identity and intention. Indeed, with the digitization of much text, the potential for the written signature to continue to mark individual identity unambiguously is increasingly in doubt. Placing the object, the signature, in its larger historical context again shows that practices of signing are contextdependent. The signature cannot develop as a marker of the individual — much less of the individual's literary capacities — without a broader historical process of humanist individuation, much work in technologies of signification, and the underpinning structures of state power. Moreover, Melançon shows that much more than simple literary incapacity may be at work in the absence of signatures on documents. People may be perfectly able to sign, but refuse to do so. When signing has become a marker of identity, those who do not wish to be identified may refuse to sign. People may erase or deface the signatures of others to undermine the authority of documents. Simple scriptoral acts turn out to be neither simple nor simply scriptoral.

Melançon is the most tolerant of our contributors to the use of signing as an index, even as he shows the wide uses to which signing or not signing documents can be put. Still, those who use signatures as proxies for capacities of literacy regularly express reservations about such a method and measure. What counts as 'a signature' is not a unitary object, since signers write more quickly or more slowly, more frequently or less frequently, and with greater or lesser approximation to a standard alphabet. Some researchers have proposed calligraphic typologies to capture such variation. M.M. Compère's study of schooling and literacy in 17th and 18th century Languedoc, for instance, distinguished four degrees of variation among signatures: smoothly and easily written; laborious, but with well-formed letters; maladroit, but legible; and ill-formed, with letters vaguely remembered that sometimes appear in reverse. ${ }^{7}$ Compère made an effort at classifying signatures and recording the prevalence of various kinds, finding $10 \%$ of them ill-formed. Yet even Compère's typology implicitly posits literacy as a skill and capacity of individuals whose kind and degree can be gleaned from a single documentary trace.

The relationship of signing to writing and reading is not uniform. In fact, there are no necessary grounds for assuming that those who sign can write, that those who can read can write, or even at the limit, that those who can write can read. The monitorial school, which took most of Europe and America by storm in the first half of the nineteenth century, taught students to write letters and words - and of course potentially their names - before, or as, they learned to read. Monitorial students commonly learned to read first as a public performative act, with no particular attention to the sense of what was read. Several monitorially-educated students have commented on having learned to write, in copying text, before they could read. As well, different ways of sign- 


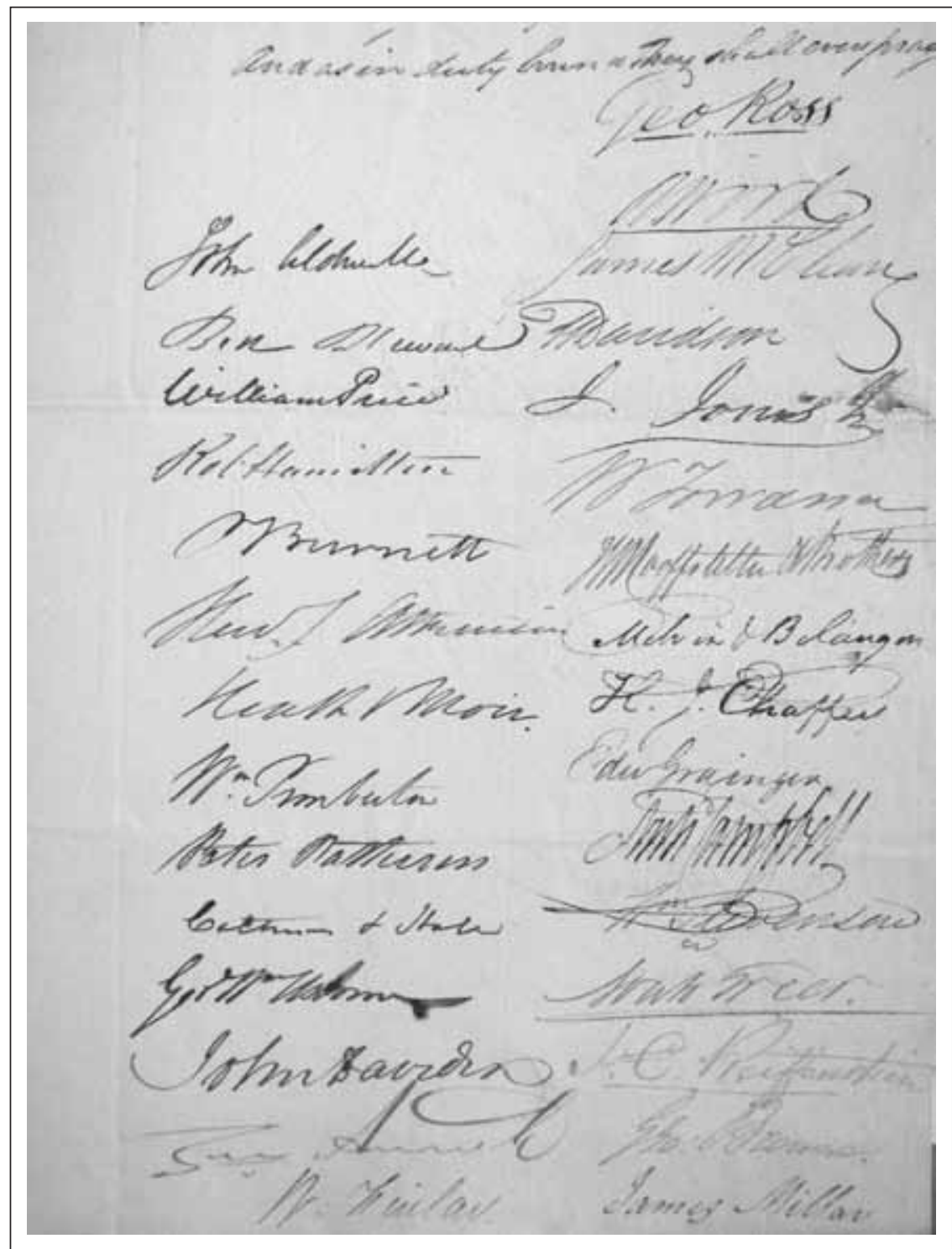

Source: Library and Archives Canada, RG4 A1 vol. 204. Signatures of the English-speaking colonial elite on a petition of 1821. There is a mixture of decorative and plain hands.

ing may point to quite different uses of writing and reading and to different social statuses. In most countries in Europe and America in the early nineteenth century, the florid signatures of members of the dominant classes contrasted sharply with the plain round hand' made general by the common school revolution. To such nineteenth century school promoters as the Canadian Egerton Ryerson, the decorative flourishes of 


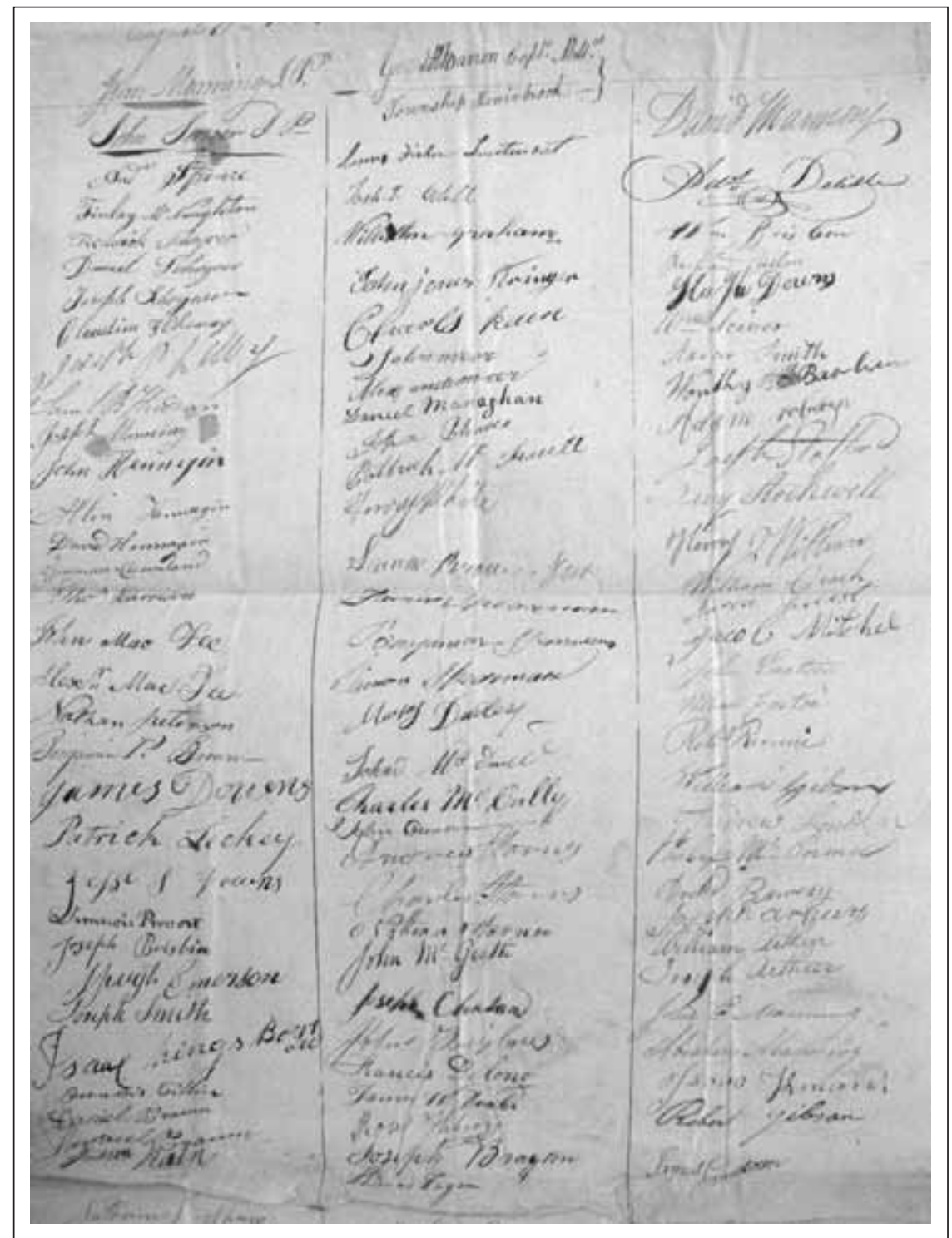

Source: Library and Archives Canada, RG4 A1 vol. 209. Signatures of English-speaking farmers in the Eastern Townships. The plain round hand dominates.

earlier penmanship were vain, idle and frivolous. Because writing was meant to convey useful and instructive information, the sparse and economical round hand was to be preferred. More generally, as the English historian of working class culture, David Vincent, put it, 'the relationship between reading and writing is far from constant either over time or between cultures.' He stresses 'the absence of any accepted criteria for measuring 
the power of literacy' in this field of study. ${ }^{8}$

La contribution des auteurs à ce numéro spécial explore l’alphabétisation par le biais de l'implantation de pratiques sociales plutôt que comme des aptitudes techniques individualisées. L'article de Steven Rowe s’appuie sur de (plus ou moins) « New Studies in Literacy " pour expliquer un déplacement théorique d'une conception de l'alphabétisme d'un savoir-faire à des pratiques. Plutôt que d'évoquer la seule dichotomie lettré/illettré, l'alphabétisation englobe un large éventail d'apprentissages et d'activités : lire, écrire, écouter, parler et, comme le démontre Michèle Martin et Thomas Götselius, voir. Les chercheurs qui adoptent cette approche font typiquement une distinction entre « literacy events » (toutes rencontres sociales avec la culture de l'imprimé) et « literacy practices " (toutes manières individuelles ou collectives de s'engager avec de telles rencontres). L'ensemble des événements et des pratiques forme un objet de recherche privilégié dans cette approche. Il n'y a pas que ceux/celles qui lisent ou qui écrivent qui sont concerné(e)s, car si l'imprimé devient omniprésent et pénètre la vie sociale, ceux/celles qui ne savent ni lire ni écrire devront aussi s'y confronter.

Dans son article, Steven E. Rowe va au-delà de l'approche encore dominante propre aux historiens du travail et de la classe ouvrière qui se préoccupent des écrits des travailleurs dans la perspective de saisir les différentes formes de leurs intérêts et projets politiques. Rowe met davantage l'accent sur les conditions sociales et les pratiques de production des écrits et de performance musicale des travailleurs français au XIX ${ }^{\mathrm{e}}$ siècle. Son exemple fascinant des goguettes ou cabarets chantants, en plein essor avant 1860 , révèle toute la richesse qu'il y a à combiner l'analyse des formes et des genres d'écriture à celle de l'interprétation. Les cabarets chantants sont particulièrement intéressants pour les historiens de l'éducation parce que c'est un domaine où les ouvriers ont effectivement produit des textes. La composition comme forme d'écriture était généralement absente des écoles étatiques ou publiques, au moins durant le XIX ${ }^{e}$ siècle. L'écriture dans ces établissements était avant tout de la copie. L'enseignement venait d'en haut et avait pour but de transmettre généralement des directives précises aux classes sociales subordonnées au lieu de présumer que les écolier(ère)s avaient ou devaient avoir des choses à exprimer. L'auteur montre que si les chansons restaient enfermées dans des genres conventionnels et souvent renforçaient des relations sexuelles de pouvoir, les goguettes se démarquent comme des institutions d'auto-expression et de composition relativement libre et poétique.

Tous les articles de cette collection traitent plus ou moins directement d'un thème commun: les relations entre l'évolution de la culture écrite et l'histoire des sens. L'idée que l'alphabétisation est une pratique ancrée dans son propre contexte, et au moyen de laquelle des sujets humains s'engagent dans un univers de textes en mouvance, encourage l'investigation des processus de constitution et d'auto-constitution des sujets de l'alphabétisation. La remarquable contribution de Thomas Götselius qui traite du « vivid alphabet " et de la généralisation de l'alphabétisation en Suède donne lieu à une analyse de la reconfiguration de la bible par Érasme comme un texte d'auteur. La notion même d'auteur apparait comme un concept issu de la pratique humaniste, notion qui changea la nature de la culture écrite. Poser la bible comme l'ouvrage du Christ et sa parole exige que ceux qui connaîtraient le Christ devraient le rencontrer en lisant par eux-mêmes. 
Comme l'expose Götselius, la lecture elle-même fut transformée par ce fait. Ainsi, cette lecture donne aux lecteur/trices accès à des visions, des sons et des sensations d'une réalité plus intense que celle de leur quotidien. Plus tard, avec les innovations pédagogiques de Comenius, le pouvoir significatif des signes de l'alphabet s'est accru grâce à une association avec des images et des sons d'une manière techniquement plus directe. Le « vivid alphabet » se réfere à un procédé encore en usage de nos jours à l'élémentaire qui illustre les lettres avec les images d'objets qui, une fois dites, expriment un son - C pour chat, par exemple. Pour sa part, la méthode phonétique a sa propre évolution. Götselius veut montrer que l'alphabétisation généralisée en Suède, habituellement attribuée au travail des pasteurs au sein des ménages, peut être mieux perçue désormais comme résultant de la généralisation de techniques développées en partie grâce aux pratiques de la pédagogie et de leur institutionnalisation par les forces militaires.

As is Götselius, but with a different subject matter and historical period, Michèle Martin is concerned with the vividness of images. Her case concerns the nineteenth century illustrated press and periodical literature, which, especially in the second half of the century, made a new form of imagery internationally accessible. While developments in Protestant countries from the sixteenth century onwards weakened the media of painted, carved, or sculpted imagery and iconography in favor of the printed word, the illustrated newspaper involved a dramatic new assertion of the power and potential of the engraved image. Mass produced and extremely cheap, the illustrated press presented its audience with new objects that were 'readable' in novel ways, connecting them to versions of contemporary events and personages with vivid immediacy. The illustrated press helped heighten the 'newness' of 'news' and gave mass audiences access to representations of famous or powerful public figures. Of course, as Martin stresses, the illustrated papers were produced by capitalist enterprises and their messages followed a 'descending' social logic, in contrast to the 'ascending' social logic of workers' self-expression in institutions such as the goguette.

Still, the illustrated press made it possible for readers of all ages and with all kinds of aptitudes to engage with print culture. Newspaper producers worked to cross the barrier between the ephemeral newspaper and the durable book by encouraging subscribers to bind their collections of papers and to preserve them as what we would now call coffee-table books. It is quite significant, as Martin shows, that the field of literacy studies does not have a set of concepts through which we might readily engage with the sorts of reading practices involved in encounters with the illustrated press. Her contribution stresses once more that the binary of literate/illiterate is incapable of rendering a wide range of practices of interest to historians of education and other students of print culture.

In presenting the material in this special issue, our hope is to make a contribution to the study of literacy and print culture that will continue moves to carry the field beyond some of its dominant tendencies. In Canada, as in many other countries, it is the history of the book that has had a particularly influential role in shaping investigations of literacy, broadly considered. Such is especially the case in my own area of research, education in colonial Lower Canada. While there are longstanding proposals for an extensive research agenda on subjects of literacy in the Lower Canadian literature, ${ }^{9}$ these tend not 
to have been taken up. Much of the work on print culture in the colony has been conducted by people who studied and worked with the influential historian Claude Galarneau, and much of this work has focused on some of the material conditions of print culture. $^{10}$

For instance, there have been extensive efforts to construct inventories of what books were imported into Lower Canada, what books booksellers sold, which ones were available in some of the main libraries, which were included in the estates of some well-to-do citizens and which were advertised in the press. Researchers have conducted time-consuming and tedious searches of sale lists in newspapers, ${ }^{11}$ but have been much less able or willing to document who read what, when, for what purpose, with what consequences. Gilles Gallichan's promisingly titled Livres et politique, for instance, provides an exhaustive account of the contents and evolution of the catalogue of the Parliamentary library. Gallichan makes it possible to see what books colonial politicians thought worth collecting. Yet in the absence of information about who borrowed which books, read which passages in them, and made what of what they read, he cannot show how particular texts may have figured in debate, policy discussion or legislation. ${ }^{12}$ It is obviously interesting and important to know what reading material was available to a public; but knowing what was available does not tell anything about what people did with it. The mere presence of books does not cause people to read them.

An important attempt to go beyond an inventory science of print culture is to be found in the essays edited by Lamonde and Montreuil in the collection Lire au Québec au XIX siècle. In Lamonde and Hardel's contribution, for instance, we see a biographical account of the politician Louis-Joseph Papineau as reader and bibliophile, particularly from the period after the Rebellion of 1837. From his correspondence with his sons especially, the authors show us how Papineau got books, what books he read and at times reread, what books he urged on his children. They show us a few of the purposes both practical (for horticulture, or to defend his seigneurial rights) and existential (his affection for Seneca as a way of dealing with life's trials) that reading served for Papineau. We hear occasional remarks about where Papineau read and at what time of day or night. Although we learn in passing that he occasionally read aloud to his family, and that he gave his censitaires school prize books, Papineau as a reader in a collectivity of readers, or Papineau whose practice of literacy was diffused in some way in the community, is largely absent. Of course, the available sources limit what the authors can discover about the impact of what Papineau read: they are for the period where Papineau, for the most part, had ceased to be a public figure of any political weight. Lamonde's earlier publication of sections of Papineau's public speeches as political leader was not concerned with Papineau the reader. ${ }^{13}$

Perhaps because the research in this collection is organized around the history of the book, rather than around reading, writing, and textually mediated social relations, it does not pursue the social and collective dimensions of literacy practice and it is the reading of books that is privileged. The editors are concerned with what they call collective as opposed to individual reading. They pose explicitly the important problem of the relation between individual readers and the whole of what is read. Yet, collective reading seems to be conceived as the aggregation of individual acts of reading, as in the creation 
of a book market, a matter of more interest to the history of the book than to the history of literacy. That the effects of reading a given text might circulate and join together to produce new phenomena seems not to be investigated. ${ }^{14}$

On the other hand, strategies of writing and speaking have been investigated in a growing Lower Canadian literature on the rhetorical arts, both as these were transmitted in classical colleges, and as they were employed in the press and in public debate. Rhetoric is such a thoroughly performative practice that the study of it can facilitate the making of connections between educational training and politics. Rhetoric can be analyzed in relation to the spoken as to the written word. ${ }^{15}$ Attempts are made in this literature to show how the rhetorical arts figured in political debate. Yet there are two important absences from it.

First, perhaps because their sources are often instruction manuals, accounts of teachers, and texts in which rhetorical training is shown at work, contributors do not address most aspects of rhetoric as active performance. Texts remain silent about the intonations, pacing, and repertoires of gesture employed by rhetoricians in speech situations. As well, there is a larger educational politics that tends to be missed. Teaching Rhetoric formed part of the classical college curriculum, monopolized by the Church, and at least from the early 1820s in Lower Canada that curriculum was subject to growing liberal and lay criticism. Liberals argued it was time-consuming and expensive, fit first and foremost to produce priests, when Lower Canadians needed to be able to compete effectively with foreign industry and commerce and with the immigrants who were monopolizing trade. French-Canadian peasant farmers, it was argued, were the least literate population in Europe or America; they urgently needed parish schools and basic instruction. Such instruction would make them better farmers, but it would also remove the political ignorance that allowed the English-speaking oligarchy to dominate them.

The liberal and lay attempts to promote parish schools generated a reaction from the Catholic and later the Anglican clergy in which the dangers of popular literacy figured centrally. Both churches shared an opposition to any educational plan that encouraged lay reading of the Bible, and spokesmen for both warned of the evil and demoralizing tendencies of unregulated reading in general. Before 1824, while Anglicans attempted to monopolize the provision of parish schooling, leading Catholic clergyman insisted repeatedly in public that as the people's guardians, they were 'forcés de les garder dans une ignorance ignominieuse' to prevent them from falling 'entre les mains des ministres ou des maîtres d'écoles d'une Religion étrangère.' ${ }^{16}$ Yet, granted the power to organize parish schooling through the Vestry School Act of 1824, the Catholic clergy did nothing effective.

My point is not to celebrate my own research interests, but to argue that the kinds of engagements that the political history of education can have with literacy events and literacy practices can usefully carry work in such areas beyond the limitations imposed upon it by other research interests, such as the history of the book. Yet educational historians themselves can better engage with the study of literacy by thinking broadly about it and by looking to ongoing scholarship in a wide range of areas to do so. The new literacy studies have pointed to the importance of ethnographic and ethnomethodological investigations of engagements with print culture, but they have 
also encouraged attention to the connections between elements of literacy practice and world-historic transformations in forms of social relations. Going beyond simple conceptions of literacy as a skill-set opens emerging fields to educational historians. As Roger Chartier has shown, a history of reading practices alone is necessarily a history of architecture, furniture, costume, gender-power, subjectification, class relations, and on. ${ }^{17}$

\section{Acknowledgements}

My thanks to the past editors of HSE/RHE for entertaining the project of this special issue and to the current editors for pursuing it; and special thanks to Rosa Bruno-Jofré for supporting the journal so generously and energetically. Without the efforts of Kate Freeman, our Managing Editor, this issue would not have seen the light of day, especially since the journal adopted the Open Journal Systems software before the project was launched: I am a total computer klutz and became a pest to Kate in consequence. I embarrassed myself twice by neglecting the software's techniques for ensuring blind reviews and then had to commission new reviews, which caused two busy colleagues extra work. My excuses to them. My thanks to Jocelyne Murray for taking on the French-language copy-editing and some translation work on short notice.

\section{Notes}

1 L[ibrary and] A[rchives] C[anada] RG4 B30 vol. 11, Trustees, L'Assomption, to Civil Secretary, 27 October 1835; text as in the original.

2 On the monster petition, Robert Christie, A History of the Late Province of Lower Canada. Parliamentary and Political. From the Commencement to the Close of its Existence as a Separate Province, vol. 3, 6 vols. (Montreal: Richard Worthington, 1866).

On petitioning generally, Steven Watt, ““Duty Bound and Every Praying”: Collective Petitioning to Governors and Legislatures in Selected Regions of Maine and Lower Canada, 1820-1838" (Ph.D. dissertation, Université du Québec à Montréal, 2006).

3 See for instance, Michel Verrette, L'Alphabétisation au Québec 1660-1900. En marche vers la modernité culturelle (Québec: Septentrion, 2002). Actually, Verrette accepts the curé's signature as the signatures of those marrying in some unspecified number of cases (see p.38).

4 Dorothy Smith, The Conceptual Practices of Power (Toronto: University of Toronto Press, 1990), ---. Writing the Social: Critique, Theory, and Investigations (Toronto: University of Toronto Press, 1999).

5 On textual economies, Bruce Curtis, "Textual Economies and the Presentation of Statistical Material: Charts, Tables and Texts in 19th Century Public Education," Scientia Canadensis 30.1 (2006): 3-29.

6 Béatrice Fraenkel, La Signature. Genèse d'un signe (Paris: Gallimard, 1992).

7 M.M. Compère, "École et alphabétisation en Languedoc aux XVII et XVIII siècles," in Lire et écrire. L'alphabétisation des français de Calvin à Jules Ferry, eds. François Furet and Jacques Ozouf, vol. 2 (Paris: les Éditions de Minuit, 1977), 43-99.

8 David Vincent, "Literacy and Popular Culture. England 1750-1914," in Cambridge Studies in Oral and Literate Culture, eds. Peter Burke and Ruth Finnegan (Cambridge: Cambridge University Press, 1989), quotations at pp. 5 and 10. 
9 Allan Greer, "The Pattern of Literacy in Quebec, 1745-1899," Histoire sociale/Social History 11 (1978): 295-335.

10 See the introduction to Yvan Lamonde and Gallichan Gilles, eds., L'histoire de la culture et de l'imprimé. Hommages à Claude Galarneau (Québec: Les Presses de l'Université Laval, 1996).

11 For instance, Réjean Lemoine, "Le commerce du livre et la lecture à Québec avant 1837," in L'histoire de la culture et de l'imprimé. Hommages à Claude Galarneau, eds. Yvan Lamonde and Gilles Gallichan (Québec: Les Presses de l'Université Laval, 1996), 163-72. This Master's thesis involved an inventory of more that 13,000 book titles advertised in two newspapers.

12 Gilles Gallichan, Livre et politique au Bas-Canada 1791-1849 (Québec: Éditions du Septentrion, 1991).

13 Yvan Lamonde and Frédéric Hardel, "Lectures domestiques, d'exil et de retraite de LouisJoseph Papineau (1823-1871)," in Lire au Québec au XIXe siècle, eds. Yvan Lamonde and Sophie Montreuil (Montréal: Éditions Fides, 2003), 19-67.

14 Lamonde, Yvan, and Sophie Montreuil, "Pour une histoire des pratiques de lecture: éléments de méthode et pacte fondateur," in Lire au Québec au XIXe siècle, eds. Yvan Lamonde and Sophie Montreuil (Montreal: Éditions Fides, 2003), 7-17.

15 Especially, Marc André Bernier, "Portrait de l'éloquence au Québec (1760-1840)," in Portrait des arts, des lettres et de l'éloquence au Québec (1760-1840), eds. Bernard Andrès and Marc André Bernier (Québec: Les Presses de l'Université Laval, 2002), 410-423. Yvan Lamonde, La philosophie et son enseignement au Québec (1665-1920) (Montréal: Hurtubise HMH, 1980).

16 "Le Campagnard", probably curé Painchaud de Ste Anne de la Pocatière, in Le Canadien 9 (May 1821).

17 Roger Chartier, "The practical impact of writing," in A History of Private Life, ed. Roger Chartier, vol. III, Passions of the Renaissance (Cambridge: Harvard University Press, 1989), 111-165; ---, ed. Pratiques de la lecture (Payot et Rivages, 1993). 
12 Historical Studies in Education/Revue d'histoire de l'éducation 